\title{
REVIEW
}

\section{Clinical review: Neuromonitoring - an update}

\author{
Nino Stocchetti*1, Peter Le Roux ${ }^{2}$, Paul Vespa ${ }^{3}$, Mauro Oddo ${ }^{4}$, Giuseppe Citerio ${ }^{5}$, Peter J Andrews ${ }^{6}$, Robert D Stevens \\ Tarek Sharshar ${ }^{8}$, Fabio S Taccone ${ }^{9}$ and Jean-Louis Vincent ${ }^{9}$
}

\begin{abstract}
Critically ill patients are frequently at risk of neurological dysfunction as a result of primary neurological conditions or secondary insults. Determining which aspects of brain function are affected and how best to manage the neurological dysfunction can often be difficult and is complicated by the limited information that can be gained from clinical examination in such patients and the effects of therapies, notably sedation, on neurological function. Methods to measure and monitor brain function have evolved considerably in recent years and now play an important role in the evaluation and management of patients with brain injury. Importantly, no single technique is ideal for all patients and different variables will need to be monitored in different patients; in many patients, a combination of monitoring techniques will be needed. Although clinical studies support the physiologic feasibility and biologic plausibility of management based on information from various monitors, data supporting this concept from randomized trials are still required.
\end{abstract}

\section{Introduction}

The overall aims of neuromonitoring are to: 1) identify worsening neurological function and secondary cerebral insults that may benefit from specific treatment(s); 2) improve pathophysiological understanding of cerebral disease in critical illness; 3) provide clear physiological data to guide and individualize therapy; 4) assist with prognostication. In this article, we will outline the neuromonitoring techniques currently in use in critically ill patients and suggest how they should be best applied to help us care for such patients. We will focus on clinically available techniques and not discuss new approaches that are still largely in the research stage of development.

*Correspondence: stocchet@policlinico.mi.it

'Milan University, Terapia Intensiva Neuroscienze, Fondazione IRCCS Ca' Granda,

Ospedale Maggiore Policlinico, Via F. Sforza 35, 20122 Milano, Italy

Full list of author information is available at the end of the article

\section{Pathophysiology of acute brain injury}

The pathophysiology of acute brain injury is complex and can involve several secondary pathological cascades that contribute to aggravate neuronal injury (Figure 1). The clinical rationale for neuromonitoring is to tailor therapy to patient-specific pathophysiology rather than to predefined thresholds or targets. It is thus important to briefly review some basic aspects of brain physiology to help understand the techniques and applications of neuromonitoring.

\section{Cerebral metabolism}

The human brain constitutes $2 \%$ of body weight, yet the energy-consuming processes that enable adequate brain function account for about $25 \%$ of total body energy expenditure and $20 \%$ of the oxygen consumption of the whole organism. Glucose is the main energy substrate of the brain and, given the low glycogen stores in the brain, brain glucose levels are highly dependent on blood glucose. Transport of glucose from the systemic circulation to the brain is a tightly regulated process mediated by specialized cell membrane glucose transporters (GLUT). Experimental and human studies show evidence of flow-metabolism uncoupling and increased glucose utilization after acute brain injury ('cerebral hyperglycolysis'). Importantly, this can occur in the absence of low cerebral blood flow (CBF) and cerebral ischemia and may lead to a state of reduced availability of the main energy substrate (glucose) with a subsequent risk of cerebral energy dysfunction [1,2]. However, hyperglycolysis also results in increased processing of glucose to pyruvate by astrocytes and conversion to lactate. Endogenous lactate, released in the extracellular space, can in turn be transferred, via specific monocarboxylate transporters, to neurons (a process known as the astrocyte-neuron lactate shuttle') [3]. Brain lactate may thus be used as an alternative aerobic energy substrate to glucose [4]. Indeed, studies in subarachnoid hemorrhage (SAH) patients suggest that a pattern of increased cerebral hyperglycolytic lactate is associated with better outcome [5].

\section{Cerebral blood flow, oxygen delivery and ischemia}

Cerebral ischemia is a frequent cause of secondary brain injury [6]. In normal conditions, reduced systemic 


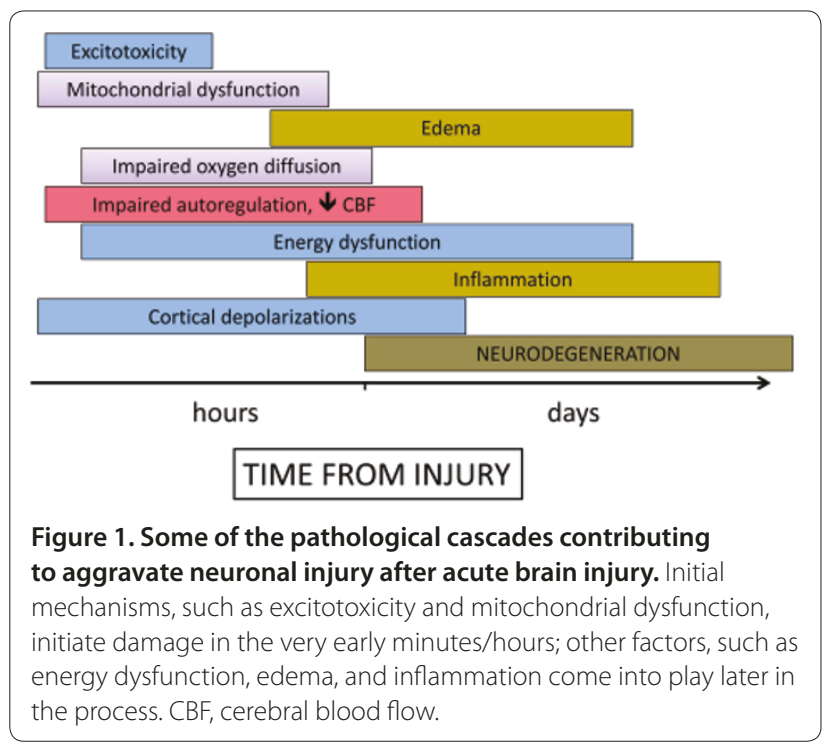

pressure triggers an active vasodilatory response that keeps cerebral blood flow (CBF) constant over a wide range of mean arterial pressures (MAPs), thereby preventing brain hypoperfusion (cerebral pressure autoregulation) [7]. In brain-injured patients, cerebrovascular reactivity may be impaired, and a decrease in MAP or cerebral perfusion pressure (CPP) may thus translate into reduced $\mathrm{CBF}$ and secondary ischemia [8].

Cerebral oxygen utilization is proportional to the product of $\mathrm{CBF}$ and the arterio-venous difference in oxygen content [9]. Mechanisms other than perfusionlimited ischemia (microvascular collapse, endothelial swelling, perivascular edema) may increase the diffusion gradient for oxygen between venous blood and brain tissue $\left(\mathrm{PvO}_{2}-\mathrm{PbtO}_{2}\right)$, reduce cellular oxygen delivery and attenuate the ability of the brain to increase oxygen extraction fraction in response to reduced CBF [10].

\section{Neurological examination of the ICU patient}

Clinical neurological examination is a fundamental component of neuromonitoring and should take into account the effects of sedative drugs, which may markedly influence neurological responses. The degree of awareness should first be assessed. Clinical assessment is based mainly on evaluating eye and motor responses to verbal orders and noxious stimuli. The depth of coma can be evaluated by the Glasgow Coma Scale (GCS) [11] or the Full Outline of UnResponsiveness (FOUR) score [12], which includes assessment of the pupillary light and corneal reflexes and of the breathing pattern. Delirium is a fluctuating state characterized by altered attention, spatio-temporal disorientation, disorganized thinking and alteration of awareness. Delirious patients can be hypoactive, hyperactive or both alternately. The Confusion
Assessment Method for the ICU (CAM-ICU) [13] or the ICU Delirium Screening Checklist (ICU DSC) [14] can be used to assess the presence and degree of delirium.

Neurological examination should then assess for neck stiffness, motor responses, plantar and deep tendon reflexes and cranial nerve functions. The presence of focal neurological signs should prompt brain imaging, which should also be considered, along with an electroencephalogram (EEG), if there is no obvious cause for delirium or coma.

\section{Monitoring techniques Intracranial pressure}

Elevated intracranial pressure (ICP; $>20 \mathrm{mmHg}$ ) is associated with increased mortality after acute traumatic brain injury (TBI) [15]. The most recent Brain Trauma Foundation guidelines [16] recommend (level II evidence) that ICP should be monitored in all salvageable patients with severe TBI (GCS score of 3 to 8 after resuscitation) and an abnormal head $\mathrm{CT}$ scan.

ICP monitoring is also used in non-traumatic neurological disorders, such as $\mathrm{SAH}$, and to a lesser extent in brain tumors, infarctions, intracerebral hemorrhage, and infections. After $\mathrm{SAH}$, external ventricular drainage is recommended in patients with higher World Federation of Neurological Societies (WFNS) scale scores or acute hydrocephalus [17], to monitor ICP and to drain cerebrospinal fluid (CSF) for ICP control. In spontaneous intracerebral hemorrhage, ICP monitoring is seldom used, but recent guidelines [18] suggest that in patients with a GCS score of $<8$, those with clinical evidence of transtentorial herniation, or those with intraventricular hemorrhage or hydrocephalus, ICP monitoring and treatment may be considered (class IIb; level of evidence: $C$ ).

ICP is a function of intracranial content: some content is easy to detect and correct, such as an expanding contusion, while others are more difficult - for example, in cases of diffuse cerebral swelling, which may indicate vasodilation or edema. The volume-pressure curve, which describes ICP changes to corresponding increases in volume, has an exponential shape: as long as compensatory mechanisms can be used (that is, displacement of CSF from the supratentorial space into the spinal sac), ICP will remain constant despite the volume increase. When compensatory capabilities are exceeded, ICP rises sharply. Attempts have been made to identify loss of compensation using ICP waveform analysis: the normal ICP waveform has three components (P1 > P2 > P3), but is altered when pressure increases, with an increase in the P2 component compared to P1 (Figure 2); the ICP pulse amplitude (difference between systolic and diastolic values) also tends to increase [19]. However, this feature depends on the CPP and on the physical properties of the measuring system, and so should be used with caution. 


\section{Normal compliance}

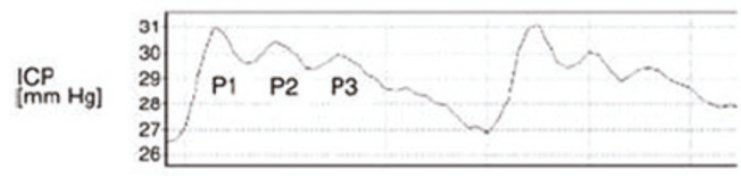

\section{P1-predominant pattern wave}

\section{Reduced compliance}

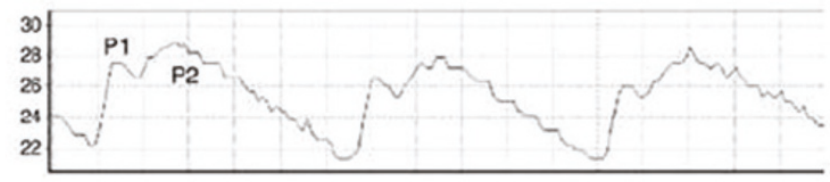

\section{P2-predominant pattern wave}

Figure 2. Intracranial pressure curve in conditions of normal and reduced compliance. Valuable information on intracranial buffering mechanisms can be extracted from the shape of the curves: when all normal components (peaks) of the intracranial pressure (ICP) curve are clearly evident (left panel), the intracranial system is behaving normally and small increases in volume can still be compensated for. However, when a P2predominant pattern is displayed (right panel), the intracranial system is less compliant and compensatory abilities are reduced.

Although non-invasive evaluation of ICP is possible using the transcranial Doppler (TCD)-derived pulsatility index [20] or optic nerve sonography [21], the only methods for continuous on-line monitoring of ICP remain invasive. Intra-ventricular devices have long been considered the 'gold standard'; however, intra-parenchymal pressure monitoring provides equivalent pressure measurements [22]. Intraventricular probes are particularly useful when CSF drainage is desirable.

ICP management should also take CPP into account (Figure 3). Therapies to reduce intracranial hypertension that also may reduce arterial pressure and CPP (for example, barbiturates) require careful titration to preserve adequate cerebral perfusion.

\section{Cerebral blood flow}

Direct, continuous measurement of regional CBF is now feasible using a thermal diffusion probe (TDP; Hemedex Cambridge, Massachusetts, USA) inserted into the brain parenchyma. The sensor at the tip provides a quantitative measure in the volume of tissue surrounding the sensor. The TDP technique showed good agreement with CBF measured by xenon-CT [23].

Correct and stable positioning of regional CBF probes with a skull bolt is crucial and a CT-scan should be performed to verify correct placement. Precise quantification of regional CBF using a TDP is dependent on the presence of a stable temperature and may be altered in conditions of hyperthermia or rapid fluctuation in a patient's temperature.

In patients with SAH, Muench and colleagues [24] used TDP monitoring to guide medical therapy for delayed cerebral ischemia, and demonstrated that increasing blood pressure with vasopressors was the only intervention that improved $\mathrm{CBF}$ and $\mathrm{PbtO}_{2}$; hypervolemia and hemodilution had only marginal effects at best. Hence, normovolemia and MAP/CPP augmentation are increasingly used instead of 'triple- $\mathrm{H}$ ' therapy in these patients.
TDP monitoring may also guide CPP management after TBI [25]. TDP data are currently limited to small singlecenter studies and larger trials are needed to confirm the validity and use of this technique.

\section{Transcranial Doppler}

Direct measurement of blood flow in the brain arteries would be of value in all cases of brain damage. Using an ultrasound probe, flow velocity (rather than flow itself) can be measured in the main arteries of the base of the brain. TCD combines ultrasound and the Doppler principle to represent erythrocyte flow in the basal cerebral arteries. In some $10 \%$ of patients, transtemporal insonation is not feasible because of anatomical barriers. When cerebrovascular resistance increases - for example, in vasospasm of the middle cerebral artery - systolic TCD velocity increases, whereas diastolic velocity decreases, leading to a clear increase in the pulsatility index (the ratio of the difference between systolic and diastolic flow to diastolic flow). For this reason, TCD is often used to monitor the time course of vasospasm after SAH [26]. However, correct interpretation of the pulsatility index is complex, because it depends not only on cerebrovascular resistance, but also on several systemic and cerebral variables [27].

TCD has also been used to assess cerebrovascular autoregulation in TBI and SAH patients [7]. Flow velocity responses to spontaneous or induced (with vasopressors) changes in CPP may quantify the status of static pressure autoregulation; autoregulation estimated by TCD in the middle cerebral artery correlated with autoregulation studied by positron emission tomography in TBI patients [28].

The main advantage of TCD is that it is non-invasive and can be carried out at the bedside. However, the quality of the TCD signal is operator-dependent and correct interpretation requires training. TCD signals may also vary over time with temperature, arterial carbon 


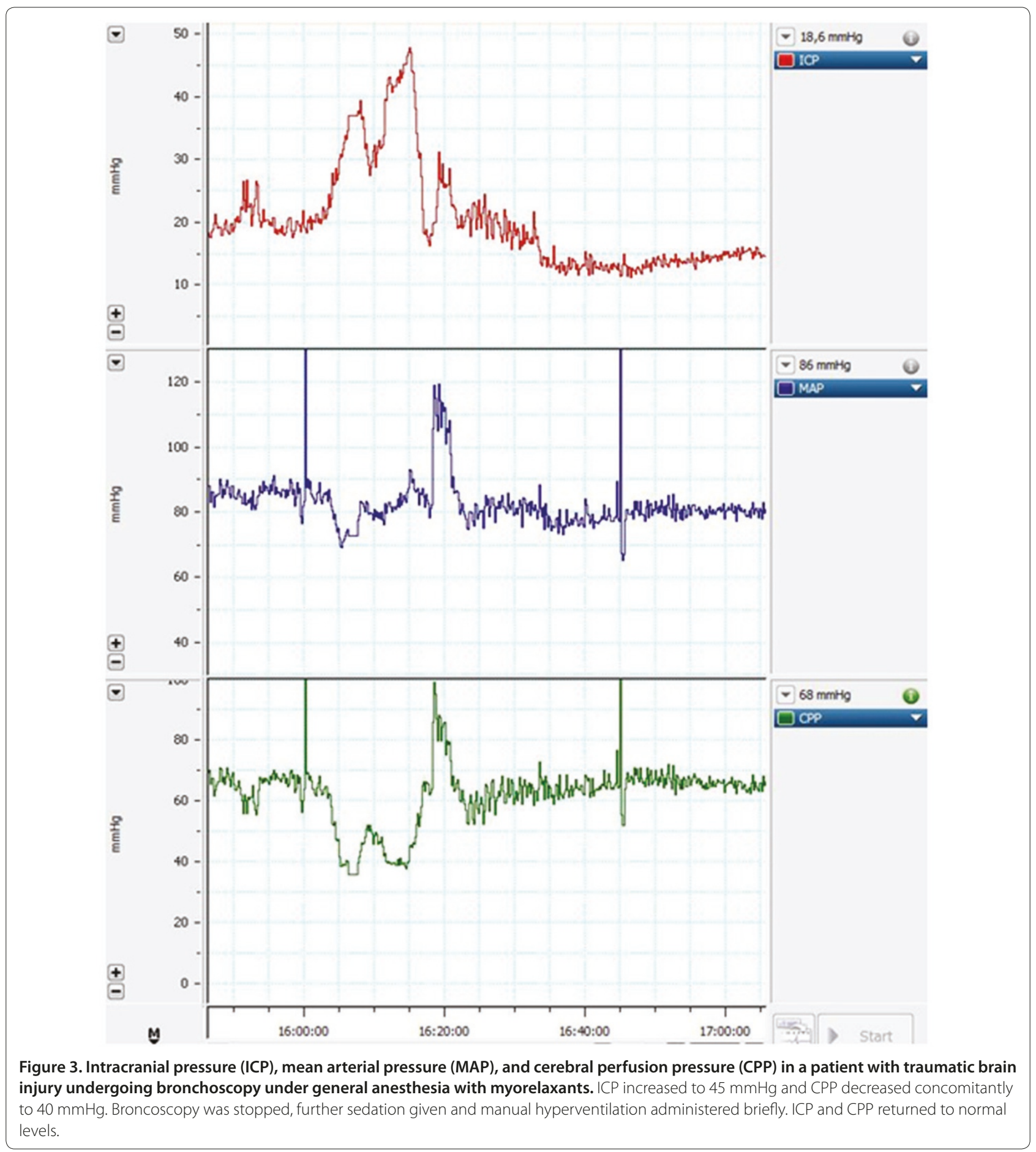

dioxide tension $\left(\mathrm{PaCO}_{2}\right.$ and, in some series, correlation with actual CBF measurements was disappointing [29].

\section{Microcirculation}

Microcirculatory alterations play a key role in the pathogenesis of organ dysfunction. Brain endothelial cells help regulate vessel diameter and permeability [30], contributing to coupling of flow to metabolism [31]. Unfortunately, it is still not possible to visualize the brain microcirculation in clinical practice without direct exposure of the cerebral cortex after craniectomy and data on microvascular abnormalities in humans are limited.

Direct evaluation of the brain microcirculation can be performed using sidestream dark field imaging and 
intravital microscopy [32]. These methods allow continuous and in vivo observation of the microcirculation at high resolution as well as evaluation of vessel size, number, density and flow. Although intravital microscopy is still considered the gold standard, it is not suitable for human use. The sidestream dark field technique can be applied on exposed cortical areas during craniectomy but care must be taken to limit pressure artifacts and minimize the risk of infection [33]. In patients with stroke from middle cerebral artery occlusion who underwent decompressive craniectomy, brain microcirculatory density and flow were significantly altered when compared to control patients [34]. Similarly, altered microvascular reactivity has been demonstrated in patients with SAH [35].

\section{Brain tissue oxygen monitoring}

Several techniques can be used to measure brain oxygenation, the most common in the ICU being jugular venous bulb oximetry and direct $\mathrm{PbtO}_{2}$ measurement. Near infra-red spectroscopy has also been used for this purpose.

\section{Jugular venous bulb oximetry}

This technique requires placement of a catheter into the jugular bulb. The arterio-jugular difference in oxygen content $\left(\mathrm{AJDO}_{2}\right)$ is proportional to $\mathrm{CBF}$ and inversely proportional to oxygen consumption (cerebral metabolic rate for oxygen, $\mathrm{CMRO}_{2}$ ) and is often used as a global measure of adequate perfusion. Proper positioning of the probe in the jugular bulb is crucial, since blood draining from extra-cerebral structures, such as the neck and face, can contaminate the lower portions of the jugular vein.

Under most conditions in which arterial hemoglobin saturation is constant, just the jugular oxygen saturation $\left(\mathrm{SjO}_{2}\right)$ is measured. This measurement can be performed by intermittent sampling, or continuously using fiberoptic probes. Normal values for $\mathrm{SjO}_{2}$ in patients without brain damage are about 57\% (95\% confidence interval 52 to $62 \%$ ) [36]. In the early hours after trauma, low $\mathrm{SjO}_{2}$ values have been detected, especially in the most severe cases [37]. Severe and frequent $\mathrm{SjO}_{2}$ desaturations are associated with worse outcome in TBI patients [38].

Because of the anatomy of the cerebral circulation, $\mathrm{SjO}_{2}$ is an average indicator and a large volume of brain must be underperfused for an abnormality to be detected. Two-thirds of the blood flowing in each jugular vein comes from the ipsilateral and one-third from the contralateral hemisphere [39]; focal areas of mismatch between flow/metabolism can, therefore, be missed by this global measurement [40]. Additionally, $\mathrm{SjO}_{2}$ values in one jugular vein may differ from values in the other [41]. Despite these limitations, intermittent $\mathrm{SjO}_{2}$ sampling is a cheap and relatively easy tool for estimating adequacy of flow and metabolism, particularly when CBF is manipulated - for example, when using hyperventilation.

\section{Direct $\mathrm{PbtO}_{2}$ measurement}

Direct $\mathrm{PbtO}_{2}$ monitors are the most common technique used in the ICU to assess cerebral oxygenation. Probe positioning is crucial: usually inserted in the white matter, readings are dependent, in part, on proximity to intracranial pathology [42]. For example, if close to a contusion, values may be reduced and this should be considered when making management decisions. When the $\mathrm{PbtO}_{2}$ probe is in what appears to be normal white matter on $\mathrm{CT}$, then the reading, although local in nature, provides a reasonable estimate of global brain oxygenation.

$\mathrm{PbtO}_{2}$ is not a 'surrogate' for ischemia or CBF, because it varies not only with $\mathrm{CBF}$ (and factors that regulate it for example, $\mathrm{CO}_{2}$ and MAP) but also with changes in arterial oxygen tension $\left(\mathrm{PaO}_{2}\right)$ among many other factors. $\mathrm{PbtO}_{2}$ is, therefore, more a marker of the balance between regional oxygen supply and cellular oxygen consumption [9].

Monitoring $\mathrm{PbtO}_{2}$ has been validated against fiberoptic $\mathrm{SjO}_{2}$ monitoring, xenon-enhanced $\mathrm{CT}$ scanning, and SPECT. Threshold values vary slightly depending on what type of $\mathrm{PbtO}_{2}$ monitor is used but values $<20 \mathrm{mmHg}$ are considered worth treating and values $<15 \mathrm{mmHg}$ indicate brain hypoxia or ischemia $[43,44]$. Decreases in $\mathrm{PbtO}_{2}$ have been associated with independent chemical markers of brain ischemia in microdialysis studies [45]. The number, duration, and intensity of brain hypoxic episodes $\left(\mathrm{PbtO}_{2}<15 \mathrm{mmHg}\right)$ and any $\mathrm{PbtO}_{2}$ values $\leq 5 \mathrm{mmHg}$ are associated with poor outcome after TBI $[46,47]$. Episodes of brain hypoxia are common and may occur even when ICP and CPP are normal [48]. The exact relationship with outcome may, however, vary according to whether the probe is positioned in normal white matter, the penumbra or in a contusion $[42,49]$. Monitoring of $\mathrm{PbtO}_{2}$ can be used in combination with other intra-parenchymal monitors, mainly ICP and cerebral microdialysis. Clinical studies suggest that therapy based on information from both an ICP and a $\mathrm{PbtO}_{2}$ monitor may be associated with better outcomes than that based on ICP monitoring alone [50].

\section{Near infra-red spectroscopy}

Oxyhemoglobin, deoxyhemoglobin, and oxidized cytochrome oxidase absorb specific portions of the light spectra. When a tissue layer is illuminated with a source of light in the near infra-red wavelength, the attenuation of the light signal is correlated to the relative proportions of oxyhemoglobin and deoxyhemoglobin $\left(\mathrm{HbO}_{2} / \mathrm{Hb}\right)$ and oxidized cytochrome oxidase in the tissue. Using appropriate calculations, an estimate of tissue oxygenation can, therefore, be made non-invasively and continuously. 
Near infra-red spectroscopy has been used in TBI [51] and SAH [52], with ambiguous results. The technique has major limitations in adults: baseline normal values vary widely, extracranial contamination is a problem, and poor correlation with independent measurements of cerebral oxygenation has been reported frequently.

\section{Microdialysis}

Cerebral microdialysis (CMD) involves the insertion of a catheter tipped with a semi-permeable membrane (usually with a $20 \mathrm{kDa}$ cutoff) in the brain parenchyma. The CMD catheter is constantly perfused, thereby allowing regular sampling of the patient's brain extracellular fluid [53]. CMD sampling is limited to the interstitial tissue area around the catheter, thus measuring regional brain metabolism. In clinical practice, a pattern of elevated lactate/pyruvate ratio and low glucose is considered as a warning sign for cerebral ischemia/hypoxia $[54,55]$. High lactate/pyruvate ratios in normoxic conditions have been interpreted as markers of hyperglycolysis. Elevated glutamate is a marker of cellular dysfunction, for example, delayed cerebral ischemia in high-risk SAH patients [56]. Absolute CMD values are important, but trends over time may provide more useful information. Recently, CMD has been used to identify the 'optimal' threshold for blood glucose during insulin therapy [57], and when used in combination with $\mathrm{PbtO}_{2}, \mathrm{CMD}$ monitoring has potential clinical utility to target adequate values of MAP/CPP [58,59] and blood hemoglobin concentration [60].

\section{Biomarkers}

Neurological biomarkers, quantitative indicators of brain dysfunction or damage, may be obtained via sampling of biological tissues (blood, CSF, brain interstitial fluid), electrophysiological recordings, or neuroimaging. For soluble biomarkers, modeling of extracerebral concentration kinetics is complex and must account for passage across anatomical barriers into the bloodstream or CSF; serum levels of a marker may therefore correlate less closely with brain levels than with alterations in bloodbrain barrier integrity. An emerging body of work suggests that multi-marker panels may enhance sensitivity and specificity for acute neurological injury [61,62]. There is also considerable interest in genomic, proteomic and lipidomic profiles.

Brain biomarkers are categorized according to their source as primarily neuronal, astroglial, or microglial. Here we briefly review the key biomarkers that have been tested clinically in acute neurological injury.

\section{$s-100 \beta$}

Increased levels of this astroglial protein are associated with injury severity and are predictive of long-term death or severe disability in severe TBI [63,64], and following cardiac arrest [65] or aneurysmal SAH [66]. Although highly sensitive, the specificity of this marker for acute brain injury is generally low [67].

\section{Glial fibrillary acidic protein}

Glial fibrillary acidic protein is associated with intermediate filaments in astrocytes. Increased serum levels are observed following moderate and severe TBI [68], ischemic stroke [69], SAH [70], and cardiac arrest [71]. Serum glial fibrillary acidic protein levels more accurately discriminate TBI outcomes than do levels of s-100 $\beta$ [72].

\section{Neuron-specific enolase}

Neuron-specific enolase is an enzyme that is found in neurons, cells of neuroendocrine origin, erythrocytes and platelets. Increased serum neuron-specific enolase has been observed in patients with ischemic stroke, TBI, SAH and after cardiac arrest $[63,65,73]$. Neuron-specific enolase can help discriminate between favorable and unfavorable outcomes following severe TBI and cardiac arrest $[63,65]$.

\section{Tau}

Tau is a neuronal protein that stabilizes microtubules, thereby promoting axonal transport. Significant elevations in tau have been observed in the CSF [74] and brain interstitial fluid [75] of patients with severe TBI. CSF tau protein is also elevated in patients with $\mathrm{SAH}$, and is associated with neurological severity and outcome [76].

\section{Amyloid $\beta$}

Amyloid $\beta$ is a peptide cleaved from neuronal and glial amyloid precursor protein. CSF amyloid $\beta$ fragment levels are lower in TBI and in SAH patients than in control subjects, and lower levels are predictive of shortterm functional outcome [77]. Recently, amyloid $\beta$ has been measured in brain interstitium [75,78].

\section{Neurofilament heavy chain}

Elevated levels of $\mathrm{NfH}$ (neurofilament heavy chain), a neuronal protein that is integral to the axonal cytoskeleton, have been reported in the brain interstitial fluid of patients with severe TBI and are associated with physiological abnormalities and mortality [79]. CSF NfH is increased following $\mathrm{SAH}$ and hypertensive intracerebral hemorrhage $[80,81]$. Serum concentrations of $\mathrm{NfH}$ do not reliably identify brain injury, perhaps because the large size of this molecule impedes passage through the blood-brain barrier.

\section{Ubiquitin carboxy-terminal hydrolase L1}

CSF levels of UCH-L1 (Ubiquitin carboxy-terminal hydrolase L1) are significantly elevated in severe TBI 
patients and are associated with lower levels of consciousness and worse six-month functional outcomes [82]. Serum levels of UCH-L1 are associated with TBI severity and survival [83].

\section{Alpha II-spectrin}

Alpha II-spectrin is a fundamental component of the neuronal cytoskeleton, which in the setting of injury is degraded into fragments referred to as spectrin breakdown products. CSF concentrations of these are elevated after TBI and correlate with the severity of injury and with six-month outcome [84]. Spectrin breakdown products are also detectable in serum and have diagnostic and prognostic value in children with TBI [85].

\section{Electro-physiological measurements Electroencephalogram}

The classical indication for EEG is to detect and manage seizures, including status epilepticus. In critically ill patients, seizures are often non-convulsive and may aggravate brain injury [86]. Intermittent EEG is less sensitive than continuous EEG for detecting nonconvulsive status epilepticus [87]. Approximately $50 \%$ of non-convulsive seizures are recorded within the first 60 minutes of EEG recording, but in some patients up to 48 hours of monitoring may be required [88]. Over the past decade, a more advanced form of EEG, quantitative EEG (qEEG), has been developed, in which the raw EEG signal is converted into a digital form using fast Fourier transformation (compressed spectral array) (Figure 4).

Several groups have used qEEG to detect seizures and other causes of brain dysfunction, such as ischemia. In SAH patients, the percent alpha trend variability (PAV) decreased acutely with the onset of vasospasm-induced decreases in CBF and returned to normal with treatment and resolution of vasospasm [89]. More recently, Rathakrishnan and colleagues [90] reported that changes in $\alpha$ power could help to distinguish delayed cerebral ischemia from vasospasm after SAH. Thus, there appears to be good evidence for the use of qEEG to detect cerebral ischemia.

qEEG may also be used to monitor the depth of sedation in the ICU. The most commonly used modality is the 'bispectral index' (BIS) [91], an algorithm-derived number that approximates the degree of sedationinduced EEG activity when patients are under general anesthesia. It ranges from 0 (brain dead) to 100 (normal brain function); a value of $<60$ indicates general anesthesia, and $<30$ indicates burst suppression.

Selected characteristics of raw EEG, such as the background rhythm and Synek scale, spontaneous variability and responsiveness stimulation, have been used to assist in estimating prognosis [92]. qEEG is more objective because it uses derived measures, and a larger amount of data that have been trended over time. The lack of PAV over time during the initial three days after severe TBI was associated with clinical outcome at 1 month [93] and 6 months [94]. PAV trends are automatically created by modern EEG software, and can be useful in tracking improvement or lack of improvement in patients in real time (Figure 5). Caution is required when using PAV and other qEEG parameters, however, because they may be affected by deep sedation.

\section{Electrocorticography and spreading depression}

Electrodes placed on the surface of the human cortex (electrocorticography), usually in proximity to damaged areas, can detect spontaneous waves of depolarization, which appear as spreading depression. Evidence is accumulating that these spreading depolarization waves cause an imbalance in energy consumption and delivery and may lead to secondary brain injury $[95,96]$. Spreading depression has been identified in TBI [97] and in patients with SAH [98] in whom the number of spreading depressions correlated significantly with the development of delayed cerebral ischemia even in the absence of vasospasm. Electrocorticography requires a craniotomy, but recent studies have suggested there may be correlates with human scalp direct and alternating current electroencephalography [99].

\section{Evoked potentials}

Somatosensory evoked potentials (SSEPs) are measured on the scalp as evoked EEG responses to an electrical stimulus applied typically to the median or tibial nerves. SSEPs are less affected by pharmacological agents or hypothermia than is the EEG. The main variable used for prognosis is the cortical response, which usually occurs at $20 \mathrm{msec}$ after the stimulus, and hence is called the N20 peak. After cardiac arrest, bilateral absence of the N20 SSEP is associated with persistent vegetative state or death in all patients $[100,101]$. SSEPs can be measured during periods of sedation and even hypothermia, but most clinicians wait for return of normothermia. There is some concern about inter- and intra-observer variability in interpretation of SSEPs [102]. The use of so-called 'cognitive' potentials, such as N70, has been suggested to improve the predictive value of poor prognosis of this test but this approach is not widely used [103].

\section{Imaging}

\section{Computed tomography}

$\mathrm{CT}$ is the imaging modality of choice in the initial evaluation of patients with TBI or when acute hemorrhage is suspected. It helps to rule out surgical masses, and to identify early signs of intracranial hypertension. Since hemorrhagic lesions or edema may evolve over the first hours after injury, a CT scan must be repeated 


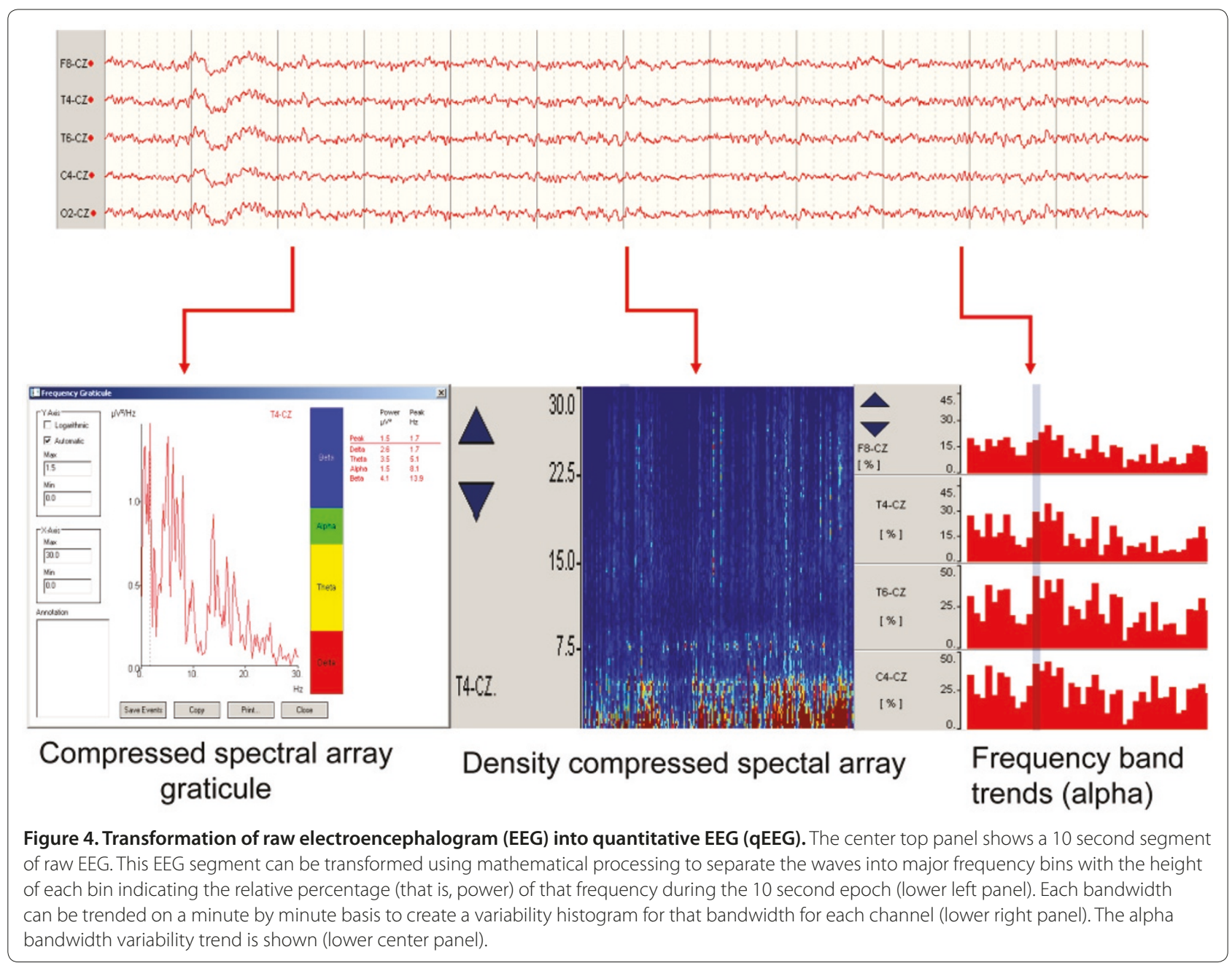

whenever there is clinical deterioration even if the initial imaging was apparently normal. The severity of TBI lesions may be classified using the Marshall [104] or Rotterdam [105] scales. New features, such as angioCT and $\mathrm{CT}$ perfusion, add important information to noncontrast $\mathrm{CT}$ and are increasingly used in stroke and $\mathrm{SAH}$ evaluation.

\section{Magnetic resonance imaging}

Magnetic resonance imaging (MRI) has great spatial resolution and, in patients with TBI, can identify pathologic abnormalities that are undetected or poorly characterized with $\mathrm{CT}$, such as traumatic axonal injury. Acute ischemic stroke can also be detected earlier using MRI than CT. MRI is multi-parametric and can provide anatomical detail and quantitative information on brain physiology and metabolism, also allowing neuronal activation to be mapped. MRI has the advantage over other radiological methods in that it does not require ionizing radiation. Challenges for MRI scanning of critically ill patients include: monitoring and resuscitation devices that are incompatible with the magnetic field, the need for sedation or even neuromuscular blockade to prevent movement artifacts, and the risks inherent to transport outside of the ICU environment.

Specific MRI sequences can enhance the diagnostic and prognostic evaluation of patients with acute brain injury.

\section{Diffusion weighted imaging}

Reductions in the apparent diffusion coefficient (ADC), a marker of water diffusion, are associated with acute tissue infarction in stroke and in cardiac arrest. Reduced $A D C$ values have been noted in major gray matter and white matter structures after cardiac arrest and are predictive of six-month outcome [106].

\section{Diffusion tensor imaging}

Diffusion tensor imaging evaluates the directional preference (anisotropy) of water diffusion and allows quantitative assessments of white matter damage in patients with TBI. The magnitude of fractional anisotropy 

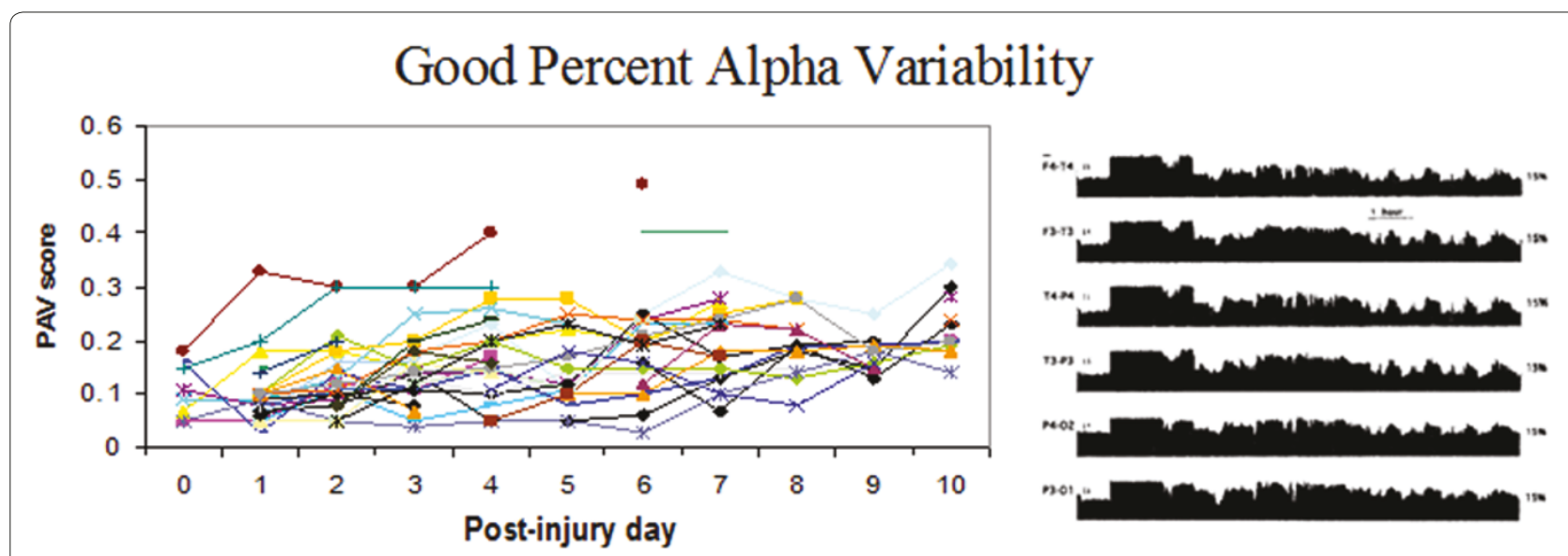

\section{Poor Percent Alpha Variability}
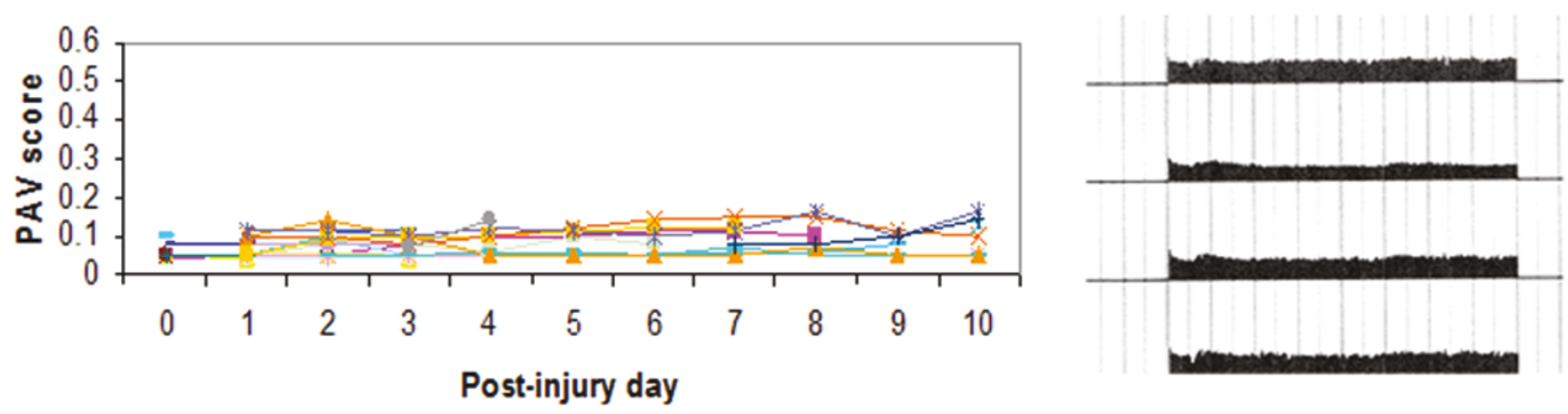

Figure 5. Lack of variability over time of the percent alpha trend (PAV) is associated with poor clinical outcomes. The daily PAV scores are graphed for those brain injured patients who eventually had a good outcome (top panel) and those that had a poor outcome (bottom panel). The PAV scores tend to remain good or improve day by day in those patients with a good outcome, whereas they remain poor or worsen day by day in those patients with a bad outcome.

change correlates with clinical TBI severity in the acute setting and with long-term outcomes $[107,108]$.

Magnetic resonance spectroscopy

Magnetic resonance spectroscopy measures tissue levels of selected neurometabolites and can provide important insight into TBI pathophysiology and natural history. It has been demonstrated that $\mathrm{N}$-acetyl aspartate, a marker of neuronal integrity, is decreased in TBI, often in brain tissue that appears normal on cranial CT or on conventional MRI. Brain $\mathrm{N}$-acetyl aspartate levels are associated with worse clinical condition and are predictive of functional outcome following TBI [108].

\section{Susceptibility weighted imaging}

Susceptibility weighted imaging is highly sensitive to microscopic hemorrhagic lesions associated with TBI, which are believed to represent a subtype of diffuse axonal injury. In children with diffuse axonal injury, the number and volume of hemorrhagic lesions seen with susceptibility weighted imaging correlates with neurological severity on initial presentation and with long-term cognitive impairment and functional disability [109].

\section{Functional MRI}

Functional MRI demonstrates that cortical-subcortical networks governing motor activity are significantly impaired following TBI [110].

\section{Integration of variables}

A single monitoring technique may not fully describe the complex pathophysiological changes in the brain and the concept of multimodality monitoring, the simultaneous digital recording of multiple parameters of brain function, has been introduced [111]. Multicenter collaborations, such as BrainIT (Brain monitoring with Information Technology collaborative network) [112], have demonstrated that recording of many physiological variables across multiple patients is feasible and can provide new clinical insights [113]. Advanced statistical and 
mathematical tools can be applied to the large volumes of data obtained with the aim of identifying patterns of brain injury and providing clinicians with easier identification of specific targets [114]. Challenges in data integration and synchronization remain, but, ultimately, this concept should provide real-time, user-friendly advanced data analysis that, when applied at the bedside, could improve treatment.

\section{Future trials}

Neurological monitoring has developed rapidly over the past 25 years with widespread application of various monitors, but, although clinical studies suggest the physiological feasibility of this concept, there are still no published data from randomized trials to support that targeting any variables improves clinical outcome.

Neurocritical care research over the past 20 years has focused on the possibility that early pharmacological intervention might improve outcome, which has deflected attention from trials designed to answer simple questions about the everyday management of acute brain injury patients, such as optimum hemoglobin transfusion thresholds, hyperventilation, and arterial pressure management after hemorrhagic stroke, for example. More extensive availability and use of neuromonitoring technology should facilitate the development of large clinical trials networks to provide the infrastructure necessary to design and conduct studies to resolve some of these issues.

\section{Conclusion}

Monitoring of brain function in critically ill patients must begin with a careful clinical evaluation. Monitoring systems typically look at single variables and there is a need to integrate/combine systems in order to obtain a full and accurate assessment of the patient's condition so as to be able to select the most appropriate therapy. Importantly, neuromonitoring is a dynamic process and not a single measurement; the ability to follow changes over time is vital to assess response to therapy and predict prognosis. No monitor will, by itself, improve patient outcomes but wise interpretation of the data and integration of the information obtained into an individualized therapeutic plan should help optimize care of critically ill patients with brain injury.

\section{Key messages}

- Monitoring of brain function should be considered in all comatose patients in the ICU.

- Brain monitoring is centered on a careful clinical examination, although this can be limited in comatose and/or sedated patients.

- The goals of neuromonitoring are to: identify worsening neurological function and secondary insults that may benefit from specific treatments; improve pathophysiological understanding of cerebral disease in critical illness; provide physiological data to guide and individualize therapy; assist in prognostication.

- At present there is no 'ideal' single brain monitor; a combination of monitoring techniques may provide better insight into brain function than a single monitor used alone.

- Trends over time and threshold values are both important when assessing brain function.

- Clinical studies suggest the physiological feasibility and biological plausibility of management based on information from various monitors but data supporting this concept from randomized trials are still required.

\section{Abbreviations}

CBF, cerebral blood flow; CMD, cerebral microdialysis; CPP, cerebral perfusion pressure; CSF, cerebrospinal fluid; $C T$, computed tomography; EEG, electroencephalogram; GCS, Glasgow Coma Scale; ICP, intracranial pressure; MAP, mean arterial pressure; MRI, magnetic resonance imaging; $\mathrm{PAV}$, percent a trend variability; $\mathrm{PbtO}_{2}$, brain tissue $\mathrm{PO}_{2}$; $\mathrm{qEEG}$, quantitative EEG; SAH, subarachnoid hemorrhage; $\mathrm{SjO}_{2}$, jugular oxygen saturation; SSEP, somatosensory evoked potential; $\mathrm{TBI}$, traumatic brain injury; $\mathrm{TCD}$, transcranial Doppler; TDP, thermal diffusion probe.

\section{Competing interests}

PLeR has received research funding from Integra and Neurologica and has received consultancy fees from Codman. PV is an advisor for Edge Pharmaceuticals, Intouch Health, and GE, has received grants from NIH, and has equity in Intouch Health. MO is supported by Grants from the Swiss National Science Foundation (grant nr. 320030_133103) and the European Critical Care Research Network (ECCRN). He is a member of the Speakers' bureau of Integra Neuroscience. GC has been involved in educational activities for Codman Italy and Codman Europe (Speakers' bureau). PJA has received honoraria from Integra life sciences and BARD/ Medivance. NS, RD, TS, FST and JLV have no conflicts of interest to declare related to this article.

\section{Author details}

'Milan University, Terapia Intensiva Neuroscienze, Fondazione IRCCS Ca' Granda, Ospedale Maggiore Policlinico, Via F. Sforza 35, 20122 Milano, Italy; 2Department of Neurosurgery, University of Pennsylvania, 235 S. 8th Street, Philadelphia, PA 19106, USA; ${ }^{3}$ Department of Neurosurgery, David Geffen School of Medicine at UCLA, 757 Westwood Blvd, Suite 6236A, Los Angeles, CA 90095, USA; ${ }^{4}$ Department of Critical Care Medicine, CHUV-University Hospital, Faculty of Biology and Medicine, University of Lausanne, Rue du Bugnon 46, BH 08.623; CH-1011 Lausanne, Switzerland; ${ }^{5}$ Neuroanestesia e Neurorianimazione, Dipartimento di Medicina Perioperatoria e Terapie Intensive, H San Gerardo, Via Pergolesi 33, 20052 Monza, Italy; ${ }^{6}$ Center for Clinical Brain Sciences, Critical Care and Pain Medicine, University of Edinburgh, Western General Hospital, Crewe Road, Edinburgh, EH4 2XU, UK; ${ }^{7}$ Division of Neuroscience Critical Care, Johns Hopkins University School of Medicine, Meyer 8-140, 600 N. Wolfe St, Baltimore, MD 21287, USA; ${ }^{8}$ Department of Intensive Care Medicine, Raymond Poincaré, Teaching Hospital and University of Versailles Saint-Quentin en Yvelines, 104 Boulevard Raymond Poincaré, 92380 Garches, France; ' Department of Intensive Care, Erasme Hospital, Université libre de Bruxelles, route de Lennik 808, 1070 Brussels, Belgium

Published: 15 January 2013

\section{References}

1. Glenn TC, Kelly DF, Boscardin WJ, McArthur DL, Vespa P, Oertel M, Hovda DA, Bergsneider M, Hillered L, Martin NA: Energy dysfunction as a predictor of outcome after moderate or severe head injury: indices of oxygen, glucose, and lactate metabolism. J Cereb Blood Flow Metab 2003, 23:1239-1250.

2. Vespa P, Bergsneider M, Hattori N, Wu HM, Huang SC, Martin NA, Glenn TC, 
McArthur DL, Hovda DA: Metabolic crisis without brain ischemia is common after traumatic brain injury: a combined microdialysis and positron emission tomography study. J Cereb Blood Flow Metab 2005, 25:763-774.

3. Pellerin L, Bouzier-Sore AK, Aubert A, Serres S, Merle M, Costalat R, Magistretti PJ: Activity-dependent regulation of energy metabolism by astrocytes: an update. Glia 2007, 55:1251-1262.

4. Bouzier-Sore AK, Voisin P, Canioni P, Magistretti PJ, Pellerin L: Lactate is a preferential oxidative energy substrate over glucose for neurons in culture. J Cereb Blood Flow Metab 2003, 23:1298-1306.

5. Oddo M, Levine JM, Frangos S, Maloney-Wilensky E, Carrera E, Daniel RT, Levivier M, Magistretti PJ, LeRoux PD: Brain lactate metabolism in humans with subarachnoid hemorrhage. Stroke 2012, 43:1418-1421.

6. Coles JP, Fryer TD, Smielewski P, Chatfield DA, Steiner LA, Johnston AJ, Downey SP, Williams GB, Aigbirhio F, Hutchinson PJ, Rice K, Carpenter TA, Clark JC, Pickard JD, Menon DK: Incidence and mechanisms of cerebral ischemia in early clinical head injury. J Cereb Blood Flow Metab 2004, 24:202-211.

7. Czosnyka M, Smielewski P, Piechnik S, Steiner LA, Pickard JD: Cerebral autoregulation following head injury. J Neurosurg 2001, 95:756-763.

8. Coles JP, Steiner LA, Johnston AJ, Fryer TD, Coleman MR, Smieleweski P, Chatfield DA, Aigbirhio F, Williams GB, Boniface S, Rice K, Clark JC, Pickard JD, Menon DK: Does induced hypertension reduce cerebral ischaemia within the traumatized human brain? Brain 2004, 127:2479-2490.

9. Rosenthal G, Hemphill JC, III, Sorani M, Martin C, Morabito D, Obrist WD, Manley GT: Brain tissue oxygen tension is more indicative of oxygen diffusion than oxygen delivery and metabolism in patients with traumatic brain injury. Crit Care Med 2008, 36:1917-1924.

10. Menon DK, Coles JP, Gupta AK, Fryer TD, Smielewski P, Chatfield DA, Aigbirhio F, Skepper JN, Minhas PS, Hutchinson PJ, Carpenter TA, Clark JC, Pickard JD: Diffusion limited oxygen delivery following head injury. Crit Care Med 2004, 32:1384-1390.

11. Teasdale G, Jennett $B$ : Assessment of coma and impaired consciousness. A practical scale. Lancet 1974, 2:81-84

12. Wijdicks EF, Bamlet WR, Maramattom BV, Manno EM, McClelland RL: Validation of a new coma scale: The FOUR score. Ann Neurol 2005, 58:585-593.

13. Ely EW, Margolin R, Francis J, May L, Truman B, Dittus R, SperoffT, Gautam S, Bernard GR, Inouye SK: Evaluation of delirium in critically ill patients: validation of the Confusion Assessment Method for the Intensive Care Unit (CAM-ICU). Crit Care Med 2001, 29:1370-1379.

14. Bergeron N, Dubois MJ, Dumont M, Dial S, Skrobik Y: Intensive Care Delirium Screening Checklist: evaluation of a new screening tool. Intensive Care Med 2001, 27:859-864

15. Marmarou A, Anderson RL, Ward JD, Choi SC, Young HF, Eisenberg HM, Foulkes MA, Marshall LF, Jane JA: Impact of ICP instability and hypotension on outcome in patients with severe head trauma. J Neurosurg Special Supp/ 1991, 75:S59-S66.

16. Bratton SL, Chestnut RM, Ghajar J, McConnell Hammond FF, Harris OA, Hartl R, Manley GT, Nemecek A, Newell DW, Rosenthal G, Schouten J, Shutter L, Timmons SD, Ullman JS, Videtta W, Wilberger JE, Wright DW: Guidelines for the management of severe traumatic brain injury. VI. Indications for intracranial pressure monitoring. J Neurotrauma 2007, 24 Suppl 1:S37-S44.

17. Bederson JB, Connolly ES Jr, Batjer HH, Dacey RG, Dion JE, Diringer MN, Duldner JE Jr, Harbaugh RE, Patel AB, Rosenwasser RH: Guidelines for the management of aneurysmal subarachnoid hemorrhage: a statement for healthcare professionals from a special writing group of the Stroke Council, American Heart Association. Stroke 2009, 40:994-1025.

18. Morgenstern LB, Hemphill JC, III, Anderson C, Becker K, Broderick JP, Connolly ES Jr, Greenberg SM, Huang JN, MacDonald RL, Messe SR, Mitchell PH, Selim M, Tamargo RJ: Guidelines for the management of spontaneous intracerebral hemorrhage: a guideline for healthcare professionals from the American Heart Association/American Stroke Association. Stroke 2010, 41:2108-2129

19. Pickard JD, Czosnyka M: Management of raised intracranial pressure. J Neurol Neurosurg Psychiatry 1993, 56:845-858.

20. Bouzat P, Francony G, Fauvage B, Payen JF: Transcranial Doppler pulsatility index for initial management of brain-injured patients. Neurosurgery 2010 67:E1863-E1864.

21. Rajajee V, Vanaman M, Fletcher JJ, Jacobs TL: Optic nerve ultrasound for the detection of raised intracranial pressure. Neurocrit Care 2011, 15:506-515.

22. Bratton SL, Chestnut RM, Ghajar J, McConnell Hammond FF, Harris OA, Hart
R, Manley GT, Nemecek A, Newell DW, Rosenthal G, Schouten J, Shutter L, Timmons SD, Ullman JS, Videtta W, Willberger JE, Wright DW: Guidelines for the management of severe traumatic brain injury. VII. Intracranial pressure monitoring technology. J Neurotrauma 2007, 24 Suppl 1:S45-S54.

23. Vajkoczy P, Roth H, Horn P, Lucke T, Thome C, Hubner U, Martin GT, Zappletal C, Klar E, Schilling L, Schmiedek P: Continuous monitoring of regional cerebral blood flow: experimental and clinical validation of a novel thermal diffusion microprobe. J Neurosurg 2000, 93:265-274

24. Muench E, Horn P, Bauhuf C, Roth H, Philipps M, Hermann P, Quintel M, Schmiedek P, Vajkoczy P: Effects of hypervolemia and hypertension on regional cerebral blood flow, intracranial pressure, and brain tissue oxygenation after subarachnoid hemorrhage. Crit Care Med 2007, 35:1844-1851.

25. Rosenthal G, Sanchez-Mejia RO, Phan N, Hemphill JC, III, Martin C, Manley GT: Incorporating a parenchymal thermal diffusion cerebral blood flow probe in bedside assessment of cerebral autoregulation and vasoreactivity in patients with severe traumatic brain injury. J Neurosurg 2011, 114:62-70.

26. Washington $\mathrm{CW}$, Zipfel GJ: Detection and monitoring of vasospasm and delayed cerebral ischemia: a review and assessment of the literature. Neurocrit Care 2011, 15:312-317.

27. de Riva N., Budohoski KP, Smielewski P, Kasprowicz M, Zweifel C, Steiner LA Reinhard M, Fabregas N, Pickard JD, Czosnyka M: Transcranial Doppler Pulsatility Index: what it is and what it isn't. Neurocrit Care 2012, 17:58-66.

28. Steiner LA, Coles JP, Johnston AJ, Chatfield DA, Smielewski P, Fryer TD, Aigbirhio Fl, Clark JC, Pickard JD, Menon DK, Czosnyka M: Assessment of cerebrovascular autoregulation in head-injured patients: a validation study. Stroke 2003, 34:2404-2409.

29. Chieregato A, Sabia G, Tanfani A, Compagnone C, Tagliaferri F, Targa L: XenonCT and transcranial Doppler in poor-grade or complicated aneurysmatic subarachnoid hemorrhage patients undergoing aggressive management of intracranial hypertension. Intensive Care Med 2006, 32:1143-1150.

30. Zonta M, Angulo MC, Gobbo S, Rosengarten B, Hossmann KA, Pozzan T, Carmignoto G: Neuron-to-astrocyte signaling is central to the dynamic control of brain microcirculation. Nat Neurosci 2003, 6:43-50

31. Panerai RB: Assessment of cerebral pressure autoregulation in humans--a review of measurement methods. Physiol Meas 1998, 19:305-338.

32. De Backer D, Ospina-Tascon G, Salgado D, Favory R, Creteur J, Vincent JL: Monitoring the microcirculation in the critically ill patient: current methods and future approaches. Intensive Care Med 2010, 36:1813-1825.

33. De Backer D, Donadello K, Taccone FS, Ospina-Tascon G, Salgado D, Vincent $J$ L: Microcirculatory alterations: potential mechanisms and implications for therapy. Ann Intensive Care 2011, 1:27.

34. Perez-Barcena J, Goedhart P, Ibanez J, Brell M, Garcia R, Llinas P, Jimenez C, Ince C: Direct observation of human microcirculation during decompressive craniectomy after stroke. Crit Care Med 2011, 39:1126-1129.

35. Pennings FA, Albrecht KW, Muizelaar JP, Schuurman PR, Bouma GJ: Abnormal responses of the human cerebral microcirculation to papaverin during aneurysm surgery. Stroke 2009, 40:317-320.

36. Chieregato A, Calzolari F, Trasforini G, Targa L, Latronico N: Normal jugular bulb oxygen saturation. J Neurol Neurosurg Psychiatry 2003, 74:784-786

37. Verweij BH, Muizelaar JP, Vinas FC: Hyperacute measurement of intracranial pressure, cerebral perfusion pressure, jugular venous oxygen saturation, and laser Doppler flowmetry, before and during removal of traumatic acute subdural hematoma. J Neurosurg 2001, 95:569-572.

38. Gopinath SP, Robertson CS, Contant CF, Hayes C, Feldman Z, Narayan RK Grossman RG: Jugular venous desaturation and outcome after head injury. J Neurol Neurosurg Psychiatry 1994, 57:717-723.

39. Shenkin HA, Harmel MH, Kety SS: Dynamic anatomy of the cerebral circulation. Arch Neurol Psychiatry 1948, 60:240-252.

40. Coles JP, Fryer TD, Coleman MR, Smielewski P, Gupta AK, Minhas PS, Aigbirhio F, Chatfield DA, Williams GB, Boniface S, Carpenter TA, Clark JC, Pickard JD, Menon DK: Hyperventilation following head injury: effect on ischemic burden and cerebral oxidative metabolism. Crit Care Med 2007, 35:568-578.

41. Stocchetti N, Paparella A, Bridelli F, Bacchi M, Piazza P, Zuccoli P. Cerebral venous oxygen saturation studied with bilateral samples in the internal jugular veins. Neurosurgery 1994, 34:38-43.

42. Ponce LL, Pillai S, Cruz J, Li X, Julia H, Gopinath S, Robertson CS: Position of probe determines prognostic information of brain tissue $\mathrm{PO} 2$ in severe traumatic brain injury. Neurosurgery 2012, 70:1492-1503.

43. Scheufler KM, Lehnert A, Rohrborn HJ, Nadstawek J, Thees C: Individual value of brain tissue oxygen pressure, microvascular oxygen saturation, 
cytochrome redox level, and energy metabolites in detecting critically reduced cerebral energy state during acute changes in global cerebral perfusion. J Neurosurg Anesthesiol 2004, 16:210-219.

44. Chang JJ, Youn TS, Benson D, Mattick H, Andrade N, Harper CR, Moore CB, Madden CJ, Diaz-Arrastia RR: Physiologic and functional outcome correlates of brain tissue hypoxia in traumatic brain injury. Crit Care Med 2009, 37:283-290.

45. Hlatky R, Valadka AB, Goodman JC, Contant CF, Robertson CS: Patterns of energy substrates during ischemia measured in the brain by microdialysis. J Neurotrauma 2004, 21:894-906.

46. Dings J, Meixensberger J, Jager A, Roosen K: Clinical experience with 118 brain tissue oxygen partial pressure catheter probes. Neurosurgery 1998, 43:1082-1095

47. van den Brink WA, van Santbrink H, Steyerberg EW, Avezaat CJ, Suazo JA, Hogesteeger C, Jansen WJ, Kloos LM, Vermeulen J, Maas Al: Brain oxygen tension in severe head injury. Neurosurgery 2000, 46:868-876.

48. Oddo M, Levine JM, Mackenzie L, Frangos S, Feihl F, Kasner SE, Katsnelson M Pukenas B, MacMurtrie E, Maloney-Wilensky E, Kofke WA, LeRoux PD: Brain hypoxia is associated with short-term outcome after severe traumatic brain injury independently of intracranial hypertension and low cerebral perfusion pressure. Neurosurgery 2011, 69:1037-1045.

49. Longhi L, Valeriani V, Rossi S, De Marchi M, Egidi M, Stocchetti N: Effects of hyperoxia on brain tissue oxygen tension in cerebral focal lesions. Acta Neurochir Supp/ 2002, 81:315-317.

50. Nangunoori R, Maloney-Wilensky E, Stiefel M, Park S, Andrew KW, Levine JM, Yang W, Le Roux PD: Brain tissue oxygen-based therapy and outcome after severe traumatic brain injury: A systematic literature review. Neurocrit Care 2012, 17:131-138.

51. Leal-Noval SR, Cayuela A, rellano-Orden V, Marin-Caballos A, Padilla V, Ferrandiz-Millon C, Corcia Y, Garcia-Alfaro C, maya-Villar R, Murillo-Cabezas F: Invasive and noninvasive assessment of cerebral oxygenation in patients with severe traumatic brain injury. Intensive Care Med 2010, 36:1309-1317.

52. Naidech AM, Bendok BR, Ault ML, Bleck TP: Monitoring with the Somanetics INVOS $5100 \mathrm{C}$ after aneurysmal subarachnoid hemorrhage. Neurocrit Care 2008, 9:326-331.

53. Hillered L, Vespa PM, Hovda DA: Translational neurochemical research in acute human brain injury: the current status and potential future for cerebral microdialysis. J Neurotrauma 2005, 22:3-41.

54. Andrews PJ, Citerio G, Longhi L, Polderman K, Sahuquillo J, Vajkoczy P: NICEM consensus on neurological monitoring in acute neurological disease. Intensive Care Med 2008, 34:1362-1370

55. Bellander BM, Cantais E, Enblad P, Hutchinson P, Nordstrom CH, Robertson C, Sahuquillo J, Smith M, Stocchetti N, Ungerstedt U, Unterberg A, Olsen NV: Consensus meeting on microdialysis in neurointensive care. Intensive Care Med 2004, 30:2166-2169.

56. Sarrafzadeh A, Haux D, Sakowitz O, Benndorf G, Herzog H, Kuechler I, Unterberg A: Acute focal neurological deficits in aneurysmal subarachnoid hemorrhage: relation of clinical course, CT findings, and metabolite abnormalities monitored with bedside microdialysis. Stroke 2003, 34:1382-1388

57. Oddo M, Schmidt JM, Carrera E, Badjatia N, Connolly ES, Presciutti M, Ostapkovich ND, Levine JM, Le Roux P, Mayer SA: Impact of tight glycemic control on cerebral glucose metabolism after severe brain injury: a microdialysis study. Crit Care Med 2008, 36:3233-3238.

58. Ko SB, Choi HA, Parikh G, Helbok R, Schmidt JM, Lee K, Badjatia N, Claassen J, Connolly ES, Mayer SA: Multimodality monitoring for cerebral perfusion pressure optimization in comatose patients with intracerebral hemorrhage. Stroke 2011, 42:3087-3092.

59. Schmidt JM, Ko SB, Helbok R, Kurtz P, Stuart RM, Presciutti M, Fernandez L, Lee K, Badjatia N, Connolly ES, Claassen J, Mayer SA: Cerebral perfusion pressure thresholds for brain tissue hypoxia and metabolic crisis after poor-grade subarachnoid hemorrhage. Stroke 2011, 42:1351-1356.

60. Oddo M, Milby A, Chen I, Frangos S, MacMurtrie E, Maloney-Wilensky E, Stiefel M, Kofke WA, Levine JM, Le Roux PD: Hemoglobin concentration and cerebral metabolism in patients with aneurysmal subarachnoid hemorrhage. Stroke 2009, 40:1275-1281.

61. Laskowitz DT, Kasner SE, Saver J, Remmel KS, Jauch EC: Clinical usefulness of a biomarker-based diagnostic test for acute stroke: the Biomarker Rapid Assessment in Ischemic Injury (BRAIN) study. Stroke 2009, 40:77-85.

62. Turck N, Vutskits L, Sanchez-Pena P, Robin X, Hainard A, Gex-Fabry M, Fouda C, Bassem H, Mueller M, Lisacek F, Puybasset L, Sanchez JC: A multiparameter panel method for outcome prediction following aneurysmal subarachnoid hemorrhage. Intensive Care Med 2010, 36:107-115.

63. Vos PE, Lamers KJ, Hendriks JC, van Haaren M, Beems T, Zimmerman C, van Geel W, de Reus H, Biert J, Verbeek MM: Glial and neuronal proteins in serum predict outcome after severe traumatic brain injury. Neurology 2004, 62:1303-1310.

64. Korfias S, Stranjalis G, Boviatsis E, Psachoulia C, Jullien G, Gregson B, Mendelow AD, Sakas DE: Serum S-100B protein monitoring in patients with severe traumatic brain injury. Intensive Care Med 2007, 33:255-260

65. Zandbergen EG, Hijdra A, Koelman JH, Hart AA, Vos PE, Verbeek MM, de Haan RJ: Prediction of poor outcome within the first 3 days of postanoxic coma. Neurology 2006, 66:62-68

66. Sanchez-Pena P, Pereira AR, Sourour NA, Biondi A, Lejean L, Colonne C, Boch AL, Al Hawari M, Abdennour L, Puybasset L: S100B as an additional prognostic marker in subarachnoid aneurysmal hemorrhage. Crit Care Med 2008, 36:2267-2273.

67. Sen J, Belli A: S100B in neuropathologic states: the CRP of the brain? J Neurosci Res 2007, 85:1373-1380.

68. Vos PE, Jacobs B, Andriessen TM, Lamers KJ, Borm GF, Beems T, Edwards M, Rosmalen CF, Vissers JL: GFAP and S100B are biomarkers of traumatic brain injury: an observational cohort study. Neurology 2010, 75:1786-1793.

69. Herrmann M, Vos P, Wunderlich MT, de Bruijn CH, Lamers KJ: Release of glial tissue-specific proteins after acute stroke: A comparative analysis of serum concentrations of protein S-100B and glial fibrillary acidic protein. Stroke 2000, 31:2670-2677.

70. Vos PE, van Gils M, Beems T, Zimmerman C, Verbeek MM: Increased GFAP and S100beta but not NSE serum levels after subarachnoid haemorrhage are associated with clinical severity. Eur J Neurol 2006, 13:632-638.

71. Kaneko T, Kasaoka S, Miyauchi T, Fujita M, Oda Y, Tsuruta R, Maekawa T: Serum glial fibrillary acidic protein as a predictive biomarker of neurological outcome after cardiac arrest. Resuscitation 2009, 80:790-794.

72. Pelinka LE, Kroepfl A, Leixnering M, Buchinger W, Raabe A, Redl H: GFAP versus $\mathrm{S} 100 \mathrm{~B}$ in serum after traumatic brain injury: relationship to brain damage and outcome. J Neurotrauma 2004, 21:1553-1561.

73. Cronberg T, Rundgren M, Westhall E, Englund E, Siemund R, Rosen I, Widner $H$, Friberg H: Neuron-specific enolase correlates with other prognostic markers after cardiac arrest. Neurology 2011, 77:623-630.

74. Ost M, Nylen K, Csajbok L, Ohrfelt AO, Tullberg M, Wikkelso C, Nellgard P, Rosengren L, Blennow K, Nellgard B: Initial CSF total tau correlates with 1-year outcome in patients with traumatic brain injury. Neurology 2006, 67:1600-1604

75. Magnoni S, Esparza TJ, Conte V, Carbonara M, Carrabba G, Holtzman DM Zipfel GJ, Stocchetti N, Brody DL: Tau elevations in the brain extracellular space correlate with reduced amyloid-beta levels and predict adverse clinical outcomes after severe traumatic brain injury. Brain 2012, 135:1268-1280.

76. Kay A, Petzold A, Kerr M, Keir G, Thompson E, Nicoll J: Temporal alterations in cerebrospinal fluid amyloid beta-protein and apolipoprotein $\mathrm{E}$ after subarachnoid hemorrhage. Stroke 2003, 34:e240-e243.

77. Franz G, Beer R, Kampfl A, Engelhardt K, Schmutzhard E, Ulmer H, Deisenhammer F: Amyloid beta 1-42 and tau in cerebrospinal fluid after severe traumatic brain injury. Neurology 2003, 60:1457-1461.

78. Brody DL, Magnoni S, Schwetye KE, Spinner ML, Esparza TJ, Stocchetti N, Zipfel GJ, Holtzman DM: Amyloid-beta dynamics correlate with neurological status in the injured human brain. Science 2008, 321:1221-1224.

79. Petzold A, Tisdall MM, Girbes AR, Martinian L, Thom M, Kitchen N, Smith M: In vivo monitoring of neuronal loss in traumatic brain injury: a microdialysis study. Brain 2011, 134:464-483.

80. Petzold A, Keir G, Kay A, Kerr M, Thompson EJ: Axonal damage and outcome in subarachnoid haemorrhage. J Neurol Neurosurg Psychiatry 2006, 77:753-759.

81. Petzold A, Rejdak K, Belli A, Sen J, Keir G, Kitchen N, Smith M, Thompson EJ: Axonal pathology in subarachnoid and intracerebral hemorrhage. J Neurotrauma 2005, 22:407-414.

82. Papa L, Akinyi L, Liu MC, Pineda JA, Tepas JJ, III, Oli MW, Zheng W, Robinson G, Robicsek SA, Gabrielli A, Heaton SC, Hannay HJ, Demery JA, Brophy GM, Layon J, Robertson CS, Hayes RL, Wang KK: Ubiquitin C-terminal hydrolase is a novel biomarker in humans for severe traumatic brain injury. Crit Care Med 2010, 38:138-144.

83. Mondello S, Papa L, Buki A, Bullock MR, Czeiter E, Tortella FC, Wang KK, Hayes 
RL: Neuronal and glial markers are differently associated with computed tomography findings and outcome in patients with severe traumatic brain injury: a case control study. Crit Care 2011, 15:R156.

84. Pineda JA, Lewis SB, Valadka AB, Papa L, Hannay HJ, Heaton SC, Demery JA, Liu MC, Aikman JM, Akle V, Brophy GM, Tepas JJ, Wang KK, Robertson CS, Hayes RL: Clinical significance of alphall-spectrin breakdown products in cerebrospinal fluid after severe traumatic brain injury. J Neurotrauma 2007, 24:354-366.

85. Berger RP, Hayes RL, Richichi R, Beers SR, Wang KK: Serum concentrations of ubiquitin C-terminal hydrolase-L1 and alphall-spectrin breakdown product $145 \mathrm{kDa}$ correlate with outcome after pediatric TBI. J Neurotrauma 2012, 29:162-167.

86. Vespa PM, Miller C, MCArthur D, Eliseo M, Etchepare M, Hirt D, Glenn TC, Martin N, Hovda D: Nonconvulsive electrographic seizures after traumatic brain injury result in a delayed, prolonged increase in intracranial pressure and metabolic crisis. Crit Care Med 2007, 35:2830-2836.

87. Pandian JD, Cascino GD, So EL, Manno E, Fulgham JR: Digital videoelectroencephalographic monitoring in the neurological-neurosurgical intensive care unit: clinical features and outcome. Arch Neurol 2004, 61:1090-1094

88. Claassen J, Mayer SA, Kowalski RG, Emerson RG, Hirsch LJ: Detection of electrographic seizures with continuous EEG monitoring in critically ill patients. Neurology 2004, 62:1743-1748.

89. Vespa PM, Nuwer MR, Juhasz C, Alexander M, Nenov V, Martin N, Becker DP: Early detection of vasospasm after acute subarachnoid hemorrhage using continuous EEG ICU monitoring. Electroencephalogr Clin Neurophysiol 1997, 103:607-615.

90. Rathakrishnan R, Gotman J, Dubeau F, Angle M: Using continuous electroencephalography in the management of delayed cerebral ischemia following subarachnoid hemorrhage. Neurocrit Care 2011, 14:152-161.

91. Klopman MA, Sebel PS: Cost-effectiveness of bispectral index monitoring. Curr Opin Anaesthesiol 2011, 24:177-181.

92. Boccagni C, Bagnato S, Sant AA, Prestandrea C, Galardi G: Usefulness of standard EEG in predicting the outcome of patients with disorders of consciousness after anoxic coma. J Clin Neurophysiol 2011, 28:489-492.

93. Vespa PM, Boscardin WJ, Hovda DA, McArthur DL, Nuwer MR, Martin NA, Nenov V, Glenn TC, Bergsneider M, Kelly DF, Becker DP: Early and persistent impaired percent alpha variability on continuous electroencephalography monitoring as predictive of poor outcome after traumatic brain injury. J Neurosurg 2002, 97:84-92.

94. Hebb MO, McArthur DL, Alger J, Etchepare M, Glenn TC, Bergsneider M, Martin N, Vespa PM: Impaired percent alpha variability on continuous electroencephalography is associated with thalamic injury and predicts poor long-term outcome after human traumatic brain injury. J Neurotrauma 2007, 24:579-590.

95. Dreier JP: The role of spreading depression, spreading depolarization and spreading ischemia in neurological disease. Nat Med 2011, 17:439-447.

96. Feuerstein D, Manning A, Hashemi P, Bhatia R, Fabricius M, Tolias C, Pahl C, Ervine M, Strong AJ, Boutelle MG: Dynamic metabolic response to multiple spreading depolarizations in patients with acute brain injury: an online microdialysis study. J Cereb Blood Flow Metab 2010, 30:1343-1355.

97. Hartings JA, Watanabe T, Bullock MR, Okonkwo DO, Fabricius M, Woitzik J, Dreier JP, Puccio A, Shutter LA, Pahl C, Strong AJ: Spreading depolarizations have prolonged direct current shifts and are associated with poor outcome in brain trauma. Brain 2011, 134:1529-1540.

98. Woitzik J, Dreier JP, Hecht N, Fiss I, Sandow N, Major S, Winkler M, Dahlem YA, Manville J, Diepers M, Muench E, Kasuya H, Schmiedek P, Vajkoczy P: Delayed cerebral ischemia and spreading depolarization in absence of angiographic vasospasm after subarachnoid hemorrhage. $J$ Cereb Blood Flow Metab 2012, 32:203-212.
99. Drenckhahn C, Winkler MK, Major S, Scheel M, Kang EJ, Pinczolits A, Grozea C, Hartings JA, Woitzik J, Dreier JP: Correlates of spreading depolarization in human scalp electroencephalography. Brain 2012, 135:853-868.

100. Robinson LR, Micklesen PJ, Tirschwell DL, Lew HL: Predictive value of somatosensory evoked potentials for awakening from coma. Crit Care Med 2003, 31:960-967.

101. Oddo M, Rossetti AO: Predicting neurological outcome after cardiac arrest. Curr Opin Crit Care 2011, 17:254-259.

102. Hakimi K, Kinney G, Kraft G, Micklesen P, Robinson L: Reliability in interpretation of median somatosensory evoked potentials in the setting of coma: factors and implications. Neurocrit Care 2009, 11:353-361.

103. Zandbergen EG, Koelman JH, de Haan RJ, Hijdra A: SSEPs and prognosis in postanoxic coma: only short or also long latency responses? Neurology 2006, 67:583-586.

104. Marshall LF, Marshall SB, Klauber MR, van Berkum Clark M, Eisenberg HM, Jane JA, Luerssen TG, Marmarou A, Foulkes MA: A new classification of head injury based on computerized tomography. J Neurosurg 1991, 75:S14-S20.

105. Maas Al, Hukkelhoven CW, Marshall LF, Steyerberg EW: Prediction of outcome in traumatic brain injury with computed tomographic characteristics: a comparison between the computed tomographic classification and combinations of computed tomographic predictors. Neurosurgery 2005, 57:1173-1182.

106. Wijman CA, Mlynash M, Caulfield AF, Hsia AW, Eyngorn I, Bammer R, Fischbein N, Albers GW, Moseley M: Prognostic value of brain diffusion-weighted imaging after cardiac arrest. Ann Neurol 2009, 65:394-402.

107. Sidaros A, Engberg AW, Sidaros K, Liptrot MG, Herning M, Petersen P, Paulson $\mathrm{OB}$, Jernigan $\mathrm{TL}$, Rostrup E: Diffusion tensor imaging during recovery from severe traumatic brain injury and relation to clinical outcome: a longitudinal study. Brain 2008, 131:559-572.

108. Tollard E, Galanaud D, Perlbarg V, Sanchez-Pena P, Le Fur Y, Abdennour L, Cozzone P, Lehericy S, Chiras J, Puybasset L: Experience of diffusion tensor imaging and $1 \mathrm{H}$ spectroscopy for outcome prediction in severe traumatic brain injury: Preliminary results. Crit Care Med 2009, 37:1448-1455.

109. Tong KA, Ashwal S, Holshouser BA, Nickerson JP, Wall CJ, Shutter LA, Osterdock RJ, Haacke EM, Kido D: Diffuse axonal injury in children: clinical correlation with hemorrhagic lesions. Ann Neurol 2004, 56:36-50.

110. Kasahara M, Menon DK, Salmond CH, Outtrim JG, Taylor Tavares JV, Carpenter TA, Pickard JD, Sahakian BJ, Stamatakis EA: Altered functional connectivity in the motor network after traumatic brain injury. Neurology 2010 75:168-176.

111. Karakis I, Montouris GD, Otis JA, Douglass $L M$, Jonas R, Velez-Ruiz N, Wilford K, Espinosa PS: A quick and reliable EEG montage for the detection of seizures in the critical care setting. J Clin Neurophysio/ 2010, 27:100-105.

112. Piper I, Chambers I, Citerio G, Enblad P, Gregson B, Howells T, Kiening K, Mattern J, Nilsson P, Ragauskas A, Sahuquillo J, Donald R, Sinnott R, Stell A: The brain monitoring with Information Technology (BrainIT) collaborative network: EC feasibility study results and future direction. Acta Neurochir (Wien) 2010, 152:1859-1871.

113. Sorani MD, Hemphill JC, III, Morabito D, Rosenthal G, Manley GT: New approaches to physiological informatics in neurocritical care. Neurocrit Care 2007, 7:45-52.

114. Maas Al, Menon DK, Lingsma HF, Pineda JA, Sandel ME, Manley GT: Reorientation of clinical research in traumatic brain injury: report of an international workshop on comparative effectiveness research. J Neurotrauma 2012, 29:32-46.

doi:10.1186/cc11513

Cite this article as: Stocchetti N, et al:: Clinical review: Neuromonitoring an update. Critical Care 2013, 17:201. 